\title{
USO DO LIVRO DIDÁTICO DE HISTÓRIA, A CARTA DE PERO VAZ DE CAMINHA E CÁLCULO
}

\author{
Alexandre da Paixão Roldão ${ }^{1}$ \\ Antonia Dalva França-Carvalho ${ }^{2}$
}

INTRODUÇÃO: O presente artigo aborda sobre a carta de Pero Vaz de Caminha em boa parte dos livros didáticos, que por muitas vezes não chegam a citar este documento histórico que é capaz de extrair informações valiosas para a compreensão de algumas mentalidades da época. O livro didático é uma ferramenta importantíssima para o aluno ter onde pesquisar, ter um chão para poder conhecer os conteúdos da historiografia. Mas será que o livro didático faz seu trabalho por si só? Será que todo livro didático é bom? O professor deve se isentar de criticar abordagens do livro e apresentar tanto os pontos positivos e negativos de tal abordagem? Qual o papel do professor?

O livro didático é uma ferramenta auxiliadora que o professor pode e deve usar, pois além de dar um chão para o aluno pisar, ele ainda pode criticar abordagens do livro, e isso acarreta em uma reflexão crítica, pois o educando perceberá que aquele livro que ele carrega todos os dias nem sempre é confiável ou é a verdade absoluta, desdobrando sua concepção por vezes ingênua da historiografia como linear, pronta, sem vida e significância para os dias de hoje. A praticidade é importante até certo ponto, a partir do momento em que ela extrapola, fazendo com que o conteúdo fique trivial e raso, ela deve ser combatida, substituindo por uma abordagem crítica, juntamente com o professor.

A união e conexão do livro com o professor é crucial para se ter essa famosa "educação crítica" tão discutida no meio universitário. A deficiência que observamos é o atraso que o material acadêmico apresenta nesses livros, especialmente em História onde o movimento de informações é constante e dinâmica, onde deve estar atento a cada movimento e mudança. O problema na idéia de História linear nos livros didáticos é evidente, e por vezes, nem mesmo os professores ajudam a tirar esta concepção dos alunos, concepção esta de que a História é organizada, linear, com conflitos que seriam inevitáveis (História-destino?) e contradições toscas, sem ou com muito pouco significado histórico para o fato estudado. Esse "modelo" de estudar ainda é forte na mentalidade estudantil em pleno séc. XXI.

\footnotetext{
${ }^{1}$ Graduando de licenciatura em História. Bolsista OBEDUC/UFPI/CAPES.

${ }^{2}$ Coordenadora Institucional do OBEDUC/UFPI/CAPES. E-mail: adalvac@uol.com.br
} 
METODOLOGIA: Para se realizar esta pesquisa utilizamos uma metodologia baseada em leituras bibliográficas e comparações entre elas. Estabelecemos contato com o material acadêmico sobre a relação da carta de Pero Vaz com a mentalidade de Portugal em contraste com a Espanha que foi extraído especificamente do artigo de João Kennedy Eugênio, "Deslumbramento e Cálculo" (1993). Logo após, o objeto de pesquisa se tornou o livro didático "História, Das sociedades sem Estado às Monarquias absolutistas, Volume 1 (2010)" do Ronaldo Vainfas.

Estudando escribas distintos da época das grandes navegações de Portugal e Espanha e analisando suas escritas, percebemos as diferentes mentalidades que ficam evidentes. No caso, foi escolhido o famoso personagem histórico Colombo para extrair suas escritas e comprar com as de Pero Vaz. Ou seja, a pesquisa foi baseada em fontes acadêmicas e didáticas, colocando em cheque alguns pontos trabalhados, como por exemplo: a falta de importância dada a um importante documento histórico que agregaria reflexões interessantes nos alunos, aliás, o papel do livro didático é muito mais do que apenas repassar conteúdo, mas possibilitar o desenvolvimento crítico do educando.

RESULTADOS E DISCUSSÃO: Quando se vê a História de uma perspectiva crítica, dificilmente se é enganado. Percebe-se que não apenas o livro didático leva o peso da responsabilidade, mas, também o professor, sendo o ponto chave para transformar a educação em algo crítico e reflexivo. O professor bem preparado saberá facilmente lidar com o uso mais apropriado do livro didático, ele irá detectar algo omisso ou errôneo e irá explanar para a turma o seu ponto de vista, sustentando o mesmo com argumentos sólidos, ou seja, não é um mero "achismo", mas algo baseado em fontes e com visão minuciosa que todo historiador deve ter, ao mesmo tempo evitando um possível "relativismo histórico", que é algo perigoso e pouco produtivo do ponto de vista cientifico. O professor crítico vai saber identificar o cálculo de Caminha no sentido da sua frieza ao relatar o que viu sem aumentar ou diminuir para melhor ou para pior, e a fantasia de Colombo, mostrando a sua vasta emoção e falta de razão ao pisar nas terras brasílicas, fazendo uma interligação disto a Portugal e Espanha, explicando que isto tem é relacionado com suas localidades nas quais tinham diferentes mentalidades, sendo Portugal com uma visão mais racionalista do mundo e Espanha mais fantasiosa e imaginária. O professor de História (por exemplo), quando formado com um olhar profundo e minucioso, ele transforma o conteúdo acrítico e visivelmente acabado em 
algo reflexivo, exercitando o mesmo nos alunos, não apenas reproduzindo o que está escrito no livro, que infelizmente ainda acontece muito, seja pela dificuldade de se trabalhar de uma forma mais científica ou até mesmo a falta de preparo na sua formação como docente, que por vezes, não estimula o raciocínio crítico e paixão pela pesquisa.

CONSIDERAÇÕES FINAIS: Esta parece ser a questão, o diagnostico: Como vamos ensinar História de forma crítica, explanando variadas fontes e pontos de vista, se aprendemos História de forma passiva, baseada em uma única fonte que por vezes é apenas reproduzida no "b a ba" pelo próprio professor, onde não detectamos nenhum

estímulo de reflexão? É o desafio da educação hoje, formar bons professores para formar bons cidadãos, ou seja, com consciência política e humana, saber de seu papel e o que fazer com ele, como transformar o defeituoso em algo bom para a sociedade. E sendo bom cidadão, será consequentemente um bom professor, pois aprendendo bem, se ensina bem.

\section{APOIO: OBEDUC/CAPES/UFPI}

\section{REFERÊNCIAS}

VAINFAS, Ronaldo; et al. História, Das sociedades sem Estado às Monarquias absolutistas. Volume 1. São Paulo: Saraiva, 2010

MARIA, Rosa Aparecida Nechi Verceze; FRANÇA, Eliziane Moreira Silvino. O livro didático e suas implicações na prática do professor nas escolas públicas de Guajará-Mirim. Amazonas: Vitória da conquista, 2008

KENNEDY, João Eugênio. Deslumbramento e Cálculo. 1993. 